\title{
Masyarakat Sipil dan Gerakan Politik: Studi Kasus Reformasi Bahrain Abdullab ${ }^{1}$ \\ Universitas Brawijaya
}

\begin{abstract}
In early 2011, countries in the Middle East and North Africa experienced a great mass movement that demanded their country leader to step down. Bahrain was one of the countries that experienced a mass movement, where the people of Bahrain demanded a government reformation that was considered authoritarian, repressive, and discriminative. The reformation that was wanted a change within the fields of politics, social, law and economy. This research aims to determine what factors causes the eruption of the mass movement in Bahrain on 2011. The writer used the concepts that the writer used to examine the problem using the concept mass movement by Eric Hoffer and the collective action by Charles Tilly and William Gamson. Based on the data there are and the theory the writer used, the factors that caused mass movement demanding reformation in Bahrain on 2011 are the disappointment from the people of Bahrain, the existence of organization and figure that's capable of mobilize the citizen, and also a special condition which is the mass movement that occurred in Egypt.
\end{abstract}

Keywords: Mass Movement, Reformation, Babrain

\section{PENDAHULUAN}

Gerakan rakyat menuntut perubahan di Timur Tengah, nampaknya telah menyebar secara cepat ke seantero Jazirah Arab. Setelah Mesir dan Tunisia, kini sebuah Negara yang menjadi basis pangkalan militer Amerika Serikat (AS) di wilayah teluk, yakni Bahrain sedang mengalami krisis politik menyusul merebaknya gerakan massa menuntut reformasi yang dilakukan oleh rakyat Bahrain yang mayoritas muslim Syiah pada 14 Februari 2011 (Kompas, 2011).

Catatan sejarah menunjukkan gerakan protes rakyat terhadap kerajaan Bahrain pada 2011 lalu, bukanlah peristiwa perdana. Gerakan ini merupakan aksi protes berulang oleh rakyat kepada dinasti al-Khalifa meski gerakan terakhir yang terbesar dibanding gerakan sebelumnya. Hal ini terlihat dalam gejolak politik tahun 1975 ketika Parlemen dibubarkan sepihak oleh Raja Hamad al-Khalifa yang mengakibatkan munculnya tuntutan rakyat untuk membentuk parlemen kembali. Dilanjutkan pada tahun 1994, tuntutan rakyat kembali mengemuka ke permukaan akibat dari perlakuan diskriminasi terhadap rakyat Bahrain yang notabene mayoritas Syiah. Pada tahun 1999, terjadi suksesi kepemimpinan dalam kerajaan dengan naiknya Raja Hamad Al-Khalifa yang diikuti dengan berbagai kebijakan reformis. Namun kebijakan reformasi tersebut hanyalah angan-angan, mengingat Undang-Undang 
Dasar Bahrain yang diamandemen pada 2001 tidak memuat hal-hal subtansi dengan tetap menjamin kekebalan hukum keluarga raja, dan membatasi partisipasi politik rakyat serta praktek diskriminasi tetap terjadi. Misalnya partai yang berbasiskan masyarakat Syiah hanya diperbolehkan menguasai maksimal 18 dari 40 kursi yang tersedia di Parlemen, di tingkat Yudikatif, keluarga kerajaan memiliki kekebalan hukum, selain itu terdapat aturan bahwa raja memiliki hak pengampunan, serta Perdana Menteri mempunyai hak untuk menunjuk langsung Ketua Mahkamah Agung.

Dalam kajian pustaka, penulis menemukan tesis bahwa eskalasi konflik yang terjadi di Bahrain antara rakyat dan Penguasa disebabkan gagalnya pihak kerajaan dalam memberikan solusi perubahan yang diharapkan rakyat. Kegagalan pihak kerajaan dikarenakan ada pengaruh dimensi regional power yang mempengaruhinya, yakni Kerajaan Arab Saudi yang notabene berideologi Salafi yang notabene bersinggungan dengan ideologi Syiah yang tidak mengingikan terjadinya reformasi politik atau demokratisasi dikhawatirkan kebebasan yang ada akan menjadi peluang naiknya tokoh - tokoh Syiah sebagai pejabat nasional mengingat 80\% masyarakat Bahrain bermazhab Syiah (Ulrichsen, 2013). Sehingga dalam kurun waktu sejak berdirinya Negara Bahrain pasca merdeka dari Inggris pada decade 1960an hingga kini, Pihak Kerajaan Bahrain selalu melakukan kebijakan represif dan otoriter untuk melanggengkan kekuasaannya. Sehinngga gerakan protes oleh rakyat terus terjadi. Hal yang menjadi celah bagi penulis adalah dalam jurnalnya Coates tidak berbicara mengenai faktorfaktor apa yang mendorong terjadinya gerakan massa pada 14 Februari 2011. Coates lebih melihat secara aspek politik dan dukungan Arab Saudi sebagai kekuatan regional yang mempengaruhi kebijakan domestik Bahrain untuk terus menekan rakyat secara represif. Menurut Coates, Arab Saudi berkepentingan untuk mengamankan kepentingan ideologi dan kepentingan keamanan Arab Saudi. Kepentingan ideologi yang dimaksud adalah krisis politik Bahrain menimbulkan ancaman ideologi terhadap Arab Saudi yang anti-Syiah. Sehingga Arab Saudi melakukan intervensi untuk meminimalisir krisis politik Bahrain dengan memberikan bantuan keamanan, dan ekonomi kepada pemerintahan Manama dengan tujuan untuk mengurangi dominasi dan ancaman Iran di Bahrain serta ancaman terhadap aset-aset diplomatik dan perdagangan dan keamanan warga negara Arab Saudi di Bahrain yang mengarah pada kepentingan geopolitik.

Artikel ini membahas faktor-faktor yang mendorong terjadinya gerakan massa menuntut reformasi di Bahrain. Penelitian ini diharapakan menjadi sumbangan khazanah 
pengetahuan dalam kajian ilmu Hubungan Internasional ditengah sedikitnya literatur yang membahas tentang persoalan gerakan protes di Bahrain.

\section{KERANGKA PEMIKIRAN}

Guna menganalisa permasalahan tersebut, penulis menggunakan Teori Gerakan massa, Eric Hoffer menyebutkan bahwa dalam banyak kasus gerakan perubahan secara mendasar ditentukan oleh dinamika dan konfigurasi kekuasaan. Yang dimaksud adalah perubahan pada gilirannya akan ditentukan oleh tarik-menarik antara kekuatan yang menghendaki perubahan dan kekuatan yang tidak menginginkan perubahan. Hoffer menekankan bahwa faktor penyebab suatu gerakan massa adalah yang pertama adanya keinginan akan perubahan. Gerakan massa yang terlibat dalam mewujudkan perubahan dengan cepat adalah gerakan revolusioner dan gerakan perjuangan nasional secara sendirisendiri atau bersama-sama. Sekumpulan rakyat akan menuntut akan adanya perubahan secara mendasar apabila mereka merasa hidupnya tidak sesuai dengan keinginan mereka. Namun rasa tidak puas saja tidak cukup untuk menimbulkan keinginan akan perubahan. Harus ada faktor lain sebelum rasa tidak puas menjelma menjadi tindakan perlawanan. Faktor tersebut adalah keyakinan akan masa depan yang lebih baik. Rakyat akan menunjukkan rasa tidak puasnya terhadap pemerintah dan meminta perubahan apabila mereka yakin dengan yang diinginkan adalah berupa perbaikan dalam bidang politik, sosial, hokum, dan ekonomi (Hoffer, 1988: 3).

Faktor kedua adalah keinginan untuk mendapatkan pengganti. Faktor ini juga merupakan faktor utama terjadinya gerakan massa di Bahrain. Tanpa adanya keinginan untuk adanya pergantian pemimpin, akan sangat sulit terjadi perubahan taraf hidup lebih baik. Selain itu penulis juga menambahkan teori aksi kolektif yang dikemukakan oleh William Gamson dan Charles Tilly. Teorisasi pada kategori ini memusatkan perhatian besar pada persaingan atau konflik perebutan kekuasaan (perebutan dukungan massa) antara pemerintah yang berkuasa dengan kelompok-kelompok penentang terorganisir. Artinya dalam pemahaman Tilly, aksi kolektif lebih dimaknai sebagai tindakan sekelompok orang secara bersama dalam mencapai tujuan bersama. Jadi berdasar definisi ini perubahan sosial dan bentuk-bentuk protes sosial merupakan bentuk dari aksi kolektif. Menurut Tilly ketidakpuasan rakyat saja (baik akibat dislokasi sosial, modernisasi atau sebab-sebab lainnya) tidak serta merta membuat mereka melakukan aksi kolektif. Rakyat yang tidak puas tidak turut berpartisipasi aktif dalam aksi kolektif kecuali mereka menjadi bagian dari satu kelompok terorganisir yang memiliki beberapa sumber daya. Menurut Tilly, dalam aksi 
kolektif terdapat dua elemen penting yakni organisasi dan sumber daya selain kondisi obyektif yang berupa ketidakpuasan yang meluas. Bahkan ancaman yang dilancarkan oleh pemerintah dan kelompok-kelompok kontra tidak bisa menyurutkan partisipasi rakyat tidak puas yang telah terorganisir dan memiliki sumber daya otonom untuk melakukan aksi kolektif (Tilly, 1978).

Sedangkan aksi kolektif menurut Gamson (1992) bertolak dari keberadaan kepentingan yang sama di masyarakat. Gamson membangun teori aksi kolektif berawal dari konsep pemikiran Mancur Olson bahwa individu dengan kepentingan yang sama biasanya mencoba mewujudkan kepentingan bersama itu sehingga kelompok individu dengan kepentingan yang sama diyakini bakal bertindak kolektif, namun tindakan ini dapat berlangsung jika ada kondisi khusus yang menyebabkan tindakan bersama ini berlangsung. Kondisi khusus yang mendorong kelompok dan individu dengan kepentingan yang sama untuk bertindak. Inilah yang selanjutnya menjadi tema sentral argumentasi Gamson. Dengan demikian, aksi kolektif terjadi ketika terbangun suatu kondisi khusus yang membuat sekelompok orang dengan kepentingan sama telah terorganisir bertindak untuk mengejar kepetingan yang sama.

Penggunaan teori diatas dipilih dengan harapan agar dapat menjelaskan aksi gerakan massa pada pemerintah Monarki Bahrain saat ini dikarenakan ketidakpuasan rakyat terhadap sistem yang Negara yang memberikan kekuasaan sewenang-wenang terhadap lembagalembaga pemerintah. Ketidakpuasan terhadap pemerintah tersebut dirasakan oleh hampir semua rakyat Bahrain sehingga ini merupakan sebuah kepentingan yang sama.

Gerakan massa yang terjadi di Bahrain tersebut juga didukung pula oleh kondisi khusuyang mendorong rakyat untuk berani turun ke jalan untuk menuntut hak-hak mereka. Kondisi khusus tersebut adalah gerakan serupa di Mesir dan Tunisia.

\section{HASIL DAN PEMBAHASAN}

\section{Kronologi Munculnya Gerakan Massa Menuntut Reformasi}

Rakyat Bahrain hidup dalam situasi dimana hak-hak mereka sebagai rakyat telah diberangus. Diawali pada tahun 1974 rakyat hidup dalam Negara yang berada dalam keadaan darurat, berdasarkan keputusan Raja Isa al-Khalifa dalam dekritnya tentang hukum keamanan negara. Hal tersebut membuat rakyat Bahrain tidak mempunyai kebebasan berbicara dan berpendapat. Namun meski begitu rakyat masih berusaha menunjukkan protes terhadap pemerintah. Pada tahun 1975 rakyat Bahrain memprotes atas dibubarkannya parlemen. Sebelumnya apada tahun 1973 Bahrain memiliki parlemen yang merupakan hasil pemilu 
terbatas tahun 1973. Namun dua tahun berikutnya Raja membubarkannya dengan dalih parlemen Bahrain dianggap gagal dan kurang efektif dalam menyikapi kebijakan - kebijakan negara. Raja melihat bahwa persoalan ini disebabkan oleh kegagalan parlemen mengesahkan diantaranya keputusan untuk membuat sistem keamanan negara dan melakukan pembaharuan peraturan bagi negara yang menggunakan fasilitas pelabuhan di wilayah perairan Jufair. Namun rakyat melihat bahwa keputusan tersebut adalah upaya Raja Isa alKhalifa untuk mengamankan kekuasaannya.

Dalam tahun tahun berikutnya, rakyat Bahrain tetap berusaha menunjukkan protes terhadap pemerintahan al-Khalifa, diantaranya upaya kudeta yang dilakukan oleh tujuh puluh tiga orang anggota front Islam yang berafiliasi dengan Teheran yang dipimpin oleh Hojjat Ol-Eslam Hadi al-Mudarrisi pada 16 Desember 1981, yang bertepatan dengan hari nasional Bahrain (BBC, 2011). Selanjutnya sepanjang tahun 1990-an gerakan protes kembali marak, meliputi pada tahun 1994 ulama kharismatik Sheikh Ali Salman, menyerukan pemulihan majlis nasional dan mengkritik keluarga yang berkuasa (IRIB, 2010). Pada tahun 1996, kudeta kembali dilakukan oleh rakyat Bahrain (IRIB, 2010). Pada tahun yang sama, Bahrain Freedom Movement (BFM) melakukan protes terhadap pemerintah berupa perlawanan dan demonstrasi atas kebijakan pemerintah yang mengabaikan kepentingan rakyat. Demo anti pemerintah ini berakibat terbunuhnya tiga puluh delapan orang rakyat sipil sehingga menimbulkan pergolakan di daerah-daerah menuntut tanggung jawab pemerintah atas peristiwa tersebut. Selain rakyat sipil, konflik antara pemerintah Bahrain dengan oposisi juga mengakibatkan tiga orang anggota oposisi tewas pada saat polisi berupaya membubarkan para demonstran, meliputi Ahmed Abdullah al Asrour, Youssef Hasan Abdul Baqi, dan Ahmad Houbay (Katzman, 2010).

Pada tahun 2002, pemilu legislatif pertama sepanjang sejarah Bahrain diboikot rakyat karena rakyat melihat kekuasaan parlemen yang terbatas. Beberapa pihak bahkan secara ekstrem menuding pemilihan majelis rendah hanyalah akal-akalan pemerintah agar terlihat demokratis. Mereka melihat bahwa anggota majelis rendah terpilih pilihan rakyat tidak mempunyai kuasa. Mendekati titik puncak, pada tahun 2010 menjelang pemilu legislatif ketegangan penguasa dengan rakyat semakin memanas, pasca ditangkapnya ratusan rakyat Bahrain dan dibredelnya media massa milik oposisi (IRIB, 2010). Puncaknya, rakyat Bahrain kembali melakukan protes pada akhir tahun 2010. Mereka menuntut adanya reformasi dan diakhirinya nasionalisasi politik Bahrain. Gerakan-gerakan yang dianggap subversif akan segera dinetralisir dengan berbagai cara, dari persuasif, koersif hingga represif. Namun upaya 
pemerintah tersebut tidak mengurangi semangat rakyat Bahrain untuk selalu menuntut reformasi. Hal tersebut terbukti ketika rakyat Tunisia dan Mesir berhasil menumbangkan Ben Ali dan Husni Mubarak, rakyat Bahrain pun melakukan gerakan serupa, namun yang membedakan rakyat Bahrain hanya menuntut reformasi.

Pada tanggal 14 Februari 2011, rakyat Bahrain melakukan gerakan massa menuntut reformasi. Pemerintah banyak melakukan upaya-upaya untuk meredam aksi tersebut namun upaya tersebut tidak membuat rakyat Bahrain mengurangi tekanan untuk meloloskan tuntutan mereka. Gerakan massa yang dilakukan rakyat Bahrain tidaklah bermaksud untuk menggulingkan kekuasaan monarki. Rakyat yang berdemo hanya menginginkan kebebasan berpolitik yang lebih besar dan diakhirinya diskriminasi di bidang sosial, hukum, dan ekonomi yang telah dilakukan oleh pemerintah. Gerakan massa di Bahrain mengusung tema "hari kemarahan" sebagaimana hal-nya sama dengan gerakan rakyat Tunisia dan Mesir. Pada 4 Maret 2011 demonstran dilaporkan telah mencapai ratusan ribu (Globalmuslim, 2011).

Semakin hari situasi semakin mencekam, gerakan massa bertambah besar, hingga akhirnya pemerintah Bahrain meminta tolong kepada negara-negara Arab di pesisir teluk Persia untuk mengirimkan armada militernya. Pada 15 Maret, pemerintah menetapkan undang-undang darurat yang bersamaan dengan masuknya pasukan militer negara-negara anggota GCC.

Dengan dikeluarkannya UU Darurat pada 15 Maret 2011, maka dapat dikatakan gerakan massa mulai tereduksi kalau tidak ingin dikatakan berakhir karena dengan diberlakukannya UU Darurat maka Pemerintah mulai melakukan penangkapan, penahanan kepada siapa saja yang terlibat dalam gerakan massa yang dimulai sejak 14 Februari 2011. Diantara yang ditahan adalah pemimpin surat kabar terkemuka Bahrain al-Wasat hingga dikabarkan telah meninggal didalam penjara (Ulrichsen, 2013). Selain itu pemerintah juga memberhentikan ribuan pegawai yang terdiri dari 2000 pegawai di sektor pemeritah dan 2400 pegawai swasta karena tidak hadir bekerja karena mengikuti aksi protes tersebut (Ulrichsen, 2013).

\section{Tuntutan Reformasi Rakyat Bahrain}

Meletusnya gerakan massa menuntut reformasi pada 14 Februari 2011 merupakan sebuah puncak akumulasi ketidakpuasan dengan kondisi yang dialami rakyat Bahrain. Hampir selama empat dekade rakyat Bahrain telah hidup dibawah rezim yang otoriter, represif, dan diskriminatif. Gerakan massa yang dilakukan rakyat Bahrain merupakan gerakan terbesar 
dalam sejarah kehidupan politik di Bahrain. Tercatat ratusan ribu massa telah berkumpul dan bersama-sama turun ke jalan demi menuntut adanya reformasi.

Tuntutan reformasi muncul di negeri yang mayoritas penduduknya berasal dari kelompok Syiah itu. Mereka merasa terdiskriminasi dan ditindas oleh pemerintah kerajaan yang berlatarbelakang kelompok Sunni. Mereka mengeluh sulitnya mendapatkan pekerjaan dan perumahan yang layak. Demonstran yang kebanyakan adalah penganut Syiah juga merasa muak dengan diskriminasi yang dialamatkan pemerintah kepada mereka. Kendati Syiah merupakan warga mayoritas, namun para penguasa merupakan penganut aliran Sunni. Bahrain dipimpin dan dikuasai oleh keluarga al-Khalifa yang menganut aliran Sunni, yang juga mendominasi kabinet. Pemerintahan juga dipimpin oleh paman sang raja yang selama 40 tahun terakhir menjabat perdana menteri. Sementara itu, 70 persen populasi Bahrain berasal dari kaum Syiah, yang selama ini diketahui sama sekali tidak memili akses terhadap kekuasaan maupun masuk ke kepolisian dan militer. Parlemen yang dipilih setiap tujuh tahun sekali pun lebih banyak berperan mengamankan pemerintah ketimbang mewakili rakyat Bahrain. Namun, pengunjuk rasa bersikap hati-hati agar tuntutan reformasi mereka tidak malah tereduksi menjadi sekadar konflik sektarian. Mereka menyebut unjuk rasa digelar bukan oleh kelompo tertentu, melainkan oleh rakyat Bahrain yang bersatu. Salah satu demonstran Fatima Seyadi mengatakan bahwa tidak ada yang agamis dari tuntutan kami (Kompas, 2011).

Dengan kondisi seperti itu maka rakyat menuntut rezim monarki Sunni yang diskriminatif diganti dengan pemerintahan baru yang lebih toleran. Rakyat tidak ingin menghapuskan kerajaan, mereka hanya ingin pemerintah yang demokratis, dan peradilan yang independen. Rakyat Bahrain sangat mencintai Raja, oleh karenanya mereka tidak berbuat anarkis dalam aksi kolektif yang sudah berlangsung 6 bulan.

Berikut tuntutan rakyat Bahrain kepada pemerintahan Raja Hamad al-Khalifa yang diwakili oleh gabungan dari tujuh partai oposisi. Tuntutan tersebut adalah
a. Meminta untuk semua tahanan politik dibebaskan,
b. Segera diadakan reformasi pemilu,
c. Reformasi pemerintahan berbasiskan monarki konstitusional,
d. Pembentukan pemerintahan nasional yang baru,
e. Menyerukan untuk diakhirnya semua diskriminasi sektarian, 
f. Mengutuk kebijakan pemerintah naturalisasi orang asing "atas dasar politik dalam upaya untuk mengubah keseimbangan demografis negara mayoritas Syiah dalam mendukung Sunni,

g. Menuntut sebuah sistem pemilihan yang adil dan otoritas legislatif yang dapat menjalankan fungsi legislasi, budgeting, dan

h. Meminta untuk dibentuk tim investigasi atas kematian korban demonstrasi.

\section{Kekecewaan Rakyat Di Bidang Politik, Sosial Ekonomi, Dan Hukum}

Gerakan massa di Bahrain yang terjadi pada 2011, merupakan sebuah akumulasi keputusasaan rakyat Bahrain. Rakyat Bahrain telah memendam kekecewaan selama 40 tahun kepada pemerintahan al-Khalifa. Salah satu kekecewaan rakyat Bahrain tersebut adalah kekecewaan di bidang politik.

Kehidupan rakyat di bidang politik pada saat dipimpin oleh pemerintahan al-Khalifa sangat tertekan. Hal tersebut terjadi karena rakyat tidak memunyai kebebasan serta dibatasi partisipasinya. Indikasinya pertama terlihat dari kebijakan Raja Isa al-Khalifa yang menyatakan negara berada dalam keadaan darurat pada tahun 1974. Dengan diberlakukannya UU Darurat, maka pemerintah mempunyai wewenang untuk menangkap dan menahan seseorang tanpa tuduhan yang jelas. Raja Isa al-Khalifa menetapkan keadaan darurat untuk membatasi pergerakan Islam aliran radikal atau ekstrim. Namun dalam prakteknya, Raja Isa al-Khalifa cenderung menerapkan upaya pencegahan terhadap gerakan-gerakan yang bisa membahayakan kedudukannya sebagai penguasa. Kedua, dibubarkannya Majelis Nasional pada tahun 1975, ditangkapnya 73 orang pada 16 Desember 1981 yang diklaim oleh pihak kerajaan sebagai anggota front pembebasan Bahrain yang berafiliasi dengan Teheran, ditahannya 4 tokoh oposisi selama 4 tahun tanpa proses peradilan setelah berunjuk rasa karena penutupan sejumlah masjid oleh aparat keamanan, ditahannya sejumlah anggota BFM pada 1996 karena melakukan protes terhadap pemerintah, serta ditahannya ribuan orang tanpa diadili dengan dakwaan terlibat pengeboman sejumlah hotel dan restoran pada tahun yang sama adalah bukti bahwa pemerintahan Isa al-Khalifa mengekang serta membatasi partisipasi rakyat di bidang politik (BBC, 2011).

Kediktatoran Raja Isa dalam memimpin rupanya diteruskan oleh anaknya, yakni Raja Hamad bin Isa al-Khalifa. Pada tahun 1999 Putra Mahkota Hamad menjadi Raja menggantikan posisi ayahnya. Dengan pergantian kepemimpinan besar harapan rakyat akan adanya perubahan dalam kehidupan politik yang bisa diterima oleh segenap rakyat Bahrain. Pada awal memerintah Raja Hamad sempat memberikan harapan kepada rakyat dengan 
diberlakukannya piagam nasional yang berisi tentang reformasi politik. Dengan diberlakukannya piagam nasional, maka terdapat perkembangan yang positif pada masa awal beliau memimpin seperti pembebasan tahan politik, penghapusan UU darurat, diadakannya pemilu parlemen, adanya kebebasan pendirian organisasi dan pers serta dibentuknya konstitusi 2001. Namun tetap saja kehidupan politik di Bahrain masih terbatas. Hal ini nampak dari kebijakan Raja Hamad yang membatasi partisipasi politik rakyat dengan berbagai cara. Misalnya, kontrol pemerintah terhadap ijin pendirian organisasi sosial yang memberikan celah bagi pemerintah untuk tidak memberi ijin kepada organisasi yang bisa mengancam legitimasi pemerintah. Pemerintah disinyalir hanya memberi ijin kepada organisasi yang tidak kritis terhadap kebijakan pemerintah. Selain itu hampir 100\% anggota eksekutif didominasi oleh keluarga Raja. Di lembaga legislatif, raja memonopoli kekuasaan melalui Dewan tinggi permusyawaratan yang berhak membatalkan seluruh produk Undang-Undang yang dihasilkan oleh majelis rendah yang notabene dipilih rakyat (Human Rights Watch, 2009). Dengan demikian maka Raja Hamad al-Khalifa hanya menerapkan liberalisasi politik yang semu. Karena apa yang dilakukan raja Hamad al-Khalifa tidak substansial menyentuh keinginan rakyat, melainkan strategi raja Hamad untuk meneguhkan kekuasaan.

Kebijakan otoriter yang terjadi di sektor politik, nampaknya meluas ke segala sektor kehidupan masyarakat Bahrain, tak terkecuali di bidang sosial ekonomi. Di bidang sosial telah terjadi diskriminasi terhadap masyarakat Syiah yang sering kali melawan rezim Manama. Sejak Bahrain memperoleh kemerdekaan pada tahun 1971, ketegangan pihak kerajaan dengan kaum Syiah terus terjadi. Masyarakat Syiah hampir selalu terlibat dalam aksi protes dan gerakan reformasi. Aksi tersebut dilakukan untuk menuntut hak-hak mereka sebagai warga negara. Namun pemerintah bereaksi secara koersif, dengan memenjarakan dan mengasingkan para tokoh politik dan agama, serta bersikap keras dan represif terhadap mereka.

Kebijakan diskriminasi tersebut diafirmasi positif oleh aktivis politik dan blogger Bahrain Mosthafa Sadiq dalam laporannya tahun 2011 yang dirilis di situs Husaini youths.com. dia membeberkan beragam aksi pemberangusan anti Syiah di negaranya. Dalam laporan itu terungkap bahwa Putra Mahkota Bahrain Salman bin Hamad al-Khalifa mendukung kebijakan anti Syiah di negara tersebut. Sadiq memaparkan bahwa gerakan adu domba antar mazhab di Bahrain dilancarkan dengan dukungan kedutaan besar Amerika Serikat dan Inggris (HRW, 2011). 
Selama satu dekade terakhir, pemerintah juga giat melakukan naturalisasi terhadap warga asing bermazhab Sunni untuk mengubah komposisi demografi di Bahrain. Upaya itu dilakukan untuk memangkas populasi mayoritas warga muslim Syiah. Terbukti dalam 20 tahun terakhir, populasi warga Syiah Bahrain turun drastis dari 80\% mejadi 70\%. Web statistik Bahrain menunjukkan bahwa sensus penduduk tahun 2001, jumlah warga Syiah mencapai 324.553 (80\%) dan Sunni 81.114 ribu penduduk (20\%) dari total 405.667 penduduk pribumi Bahrain saat itu. Sedangkan pada sensus tahun 2011 jumlah warga Syiah mengalami penurunan populasi menjadi 397.879 ribu (70\%) dan Sunni 170.520 (30\%) ribu dari total 568.339 penduduk pribumi Bahrain (IRIB, 2011). Kebijakan rasis ini terus meningkat dalam sepuluh tahun terakhir dibawah kendali putra mahkota Pangeran Salman bin Hamad alKhalifa. Data di atas berkorelasi positif dengan data tahun 2017 yang penulis himpun dari Washington Institute, menunjukkan jumlah warga Syiah menurun menjadi $62 \%$ dan Sunni meningkat hingga $38 \%$ dari total sekitar 700.000 penduduk pribumi Bahrain (Washingthon Institute, 2017).

Maraknya perlakuan diskriminatif yang diterapkan pemerintah Bahrain, diungkap oleh sekjen forum waad, Ibrahim Sharif al-Amin. Ia menegaskan bahwa pemberian status kewarganegaraan bagi warga asing merupakan kebijakan yang terencana dan muncul dari sikap fanatisme kemazhaban keluarga kerajaan al-Khalifa. Selama ini pemerintah Manama memang getol memberikan status kewarganegaraan bagi warga asing bermazhab Sunni. Upaya itu dilakukan untuk mengubah status mayoritas masyarakat Syiah di negara tersebut (Mabon, 2020).

Tidak hanya itu, sejak tahun 2010 aksi solidaritas al-Quds yang telah menjadi tradisi tahunan umat Islam dunia yang digelar setiap Jum'at Terakhir Bulan Ramadhan telah mendapat penentangan keras dari Pemerintah Bahrain. Kantor berita ABNA, Dr Maitham al-Salman ketua pihak penyelenggara aksi solidaritas hari al-Quds sedunia di Bahrain mengungkapkan kekesalannya:

"Setelah menghubungi dan meminta kepada pemerintah resmi untuk menyeenggarakan aksi tahunan ini, kami tidak juga mendapat izin.” (ABNA Indonesia, 2011).

Pada tahun yang sama ulama Syiah terkemuka Syeikh Abdul Jalil al-Miqdad telah dilarang memberikan khotbah selama dua minggu. Selain itu juga ditemukan bahwa di sejumlah buku pelajaran di sekolah-sekolah yang berada dalam kekuasaan sekte Salafi yang berisi menghina keyakinan orang-orang Syiah. Ironisnya, tidak ada sikap pemerintah untuk menanggapi soal diskriminasi tersebut. Rentetan diskriminasi juga berlanjut dalam hal 
pelayanan publik seperti ada upaya pemerintah untuk menghalangi kaum Syiah dalam kepemilikan rumah, mendapatkan layanan kesehatan, kesempatan bekerja sebagai abdi negara. Dengan fakta diatas maka sekitar 80\% masyarakat Syiah Bahrain mengalami masalah ekonomi seperti pengangguran dan kesulitan hidup (Republika, 2011).

Masyarakat Syiah Bahrain sejatinya berada di wilayah marjinal dan tidak mendapatkan fasilitas yang sama dengan saudaranya Sunni. Mengenai hal ini, Rebecca Santana, jurnalis Associated Press dalam reportasenya mengungkapkan:

"Syiah bahkan tidak bisa disebut warga kelas dua, karena lapangan kerja yang memadai, tempat yang layak dan seluruh fasilitas sosial politik di Bahrain dikuasai oleh minoritas Sunni yang mendapat dukungan dinasti al-Khalifa.” (HRW, 2011)

Tidak hanya disektor sosial, ekonomi, marginalisasi terhadap rakyat Bahrain juga terjadi di bidang hukum. Pada tahun 2001 Human Right Watch (HRW) melaporkan:

"Berdasarkan wawancara dengan penduduk Bahrain, termasuk pengacara dan pengusaha terkemuka, dan dengan orang-orang yang telah diasingkan oleh pemerintah secara paksa, sekaligus guna menganalisis hukum Bahraindan praktek hukum. "Kami menemukan dua kategori dasar pelanggaran," kata Joe Stork, Direktur advokasi Human Rights Watch Timur Tengah. "Yang pertama, berkaitan dengan penegakan hukum dan administrasi peradilan, termasuk penahanan sewenang-wenang, penyalahgunaan fisik tahanan, dan pengadilan keamanan khusus yang menyangkal hak-hak dasar proses hukum. Kategori kedua mencakup membentuk partai politik, mengkritisi kebijakan pemerintah Bahrain dengan risiko penangkapan, kekerasan fisik, dan pengasingan (Human Rights Watch, 1997).

Apa yang ditemukan oleh HRW sesuai dengan fakta-fakta di lapangan yang memperlihatkan aksi penyalahgunaan hukum yang dilakukan pemerintah misalnya pada tahun 1995, tokoh oposisi Abdul Amir al-Jamri ditangkap tanpa tuduhan yang jelas. Begitu juga pada tahun 2010, menjelang pemilu legislatif, sekitar 300 warga termasuk 27 aktivis ditangkap dan disiksa oleh aparat keamanan Bahrain, karena dianggap membahayakan negara (HRW, 2011). Pada tahun yang sama, BCHR melaporkan adanya penangkapan 23 aktivis oposisi karena dianggap mengkritik pemerintah. Selain itu pemerintah melanjutkan kesewenangannya dengan menutup lembaga-lembaga bantuan hukum dan mengambil kendali organisasi hak asasi manusia tertua negara itu, yaitu Bahrain Centre for Human Rights (BCHR). BCHR adalah LSM yang awalnya dibentuk setelah reformasi politik Raja Hamad. Cara yang digunakan untuk mematikan BCHR adalah dengan melakukan penangkapan dan penahan tokoh-tokoh penting di organisasi tersebut. 
Diskriminasi dan kebijakan represif yang dilakukan oleh pemerintah merupakan sumber kekecewaan rakyat Bahrain. Akumulasi Kekecewaan yang sudah terjadi puluhan tahun telah menjadi bom waktu yang setiap saat akan meledak. Hingga akhirnya mencapai momentum tepat untuk melakukan protes setelah pergerakan rakyat Mesir berhasil. Reformasi pemerintahan dan diakhirinya diskriminasi di sektor sosial ekonomi, dan hukum merupakan tuntutan utama bagi rakyat Bahrain. Dengan adanya reformasi, rakyat Bahrain percaya masa depan lebih baik akan tercapai.

\section{Adanya Organisasi Atau Tokoh Yang Memobilisasi Massa}

Sebagaimana disebutkan oleh Tilly, rakyat yang tidak puas tidak akan turut berpartisipasi aktif dalam aksi kolektif kecuali mereka menjadi bagian dari suatu kelompok terorganisir yang mempunyai suatu sumber daya. Dalam gerakan massa di Bahrain, peranan ini dipegang oleh partai al-Wefaq. Al-Wefaq merupakan partai terbesar dan berpengaruh di Bahrain. Partai ini dipimpin seorang tokoh yang kharismatik, yaitu Sheikh Ali Selman. Partai ini berdiri 07 November 2001. Kekuatan partai ini cukup berpengaruh, dan memiliki 18 anggota majelis rendah dari total 40 anggota majelis rendah Bahrain (Hanafi, 2011).

Pada 14 Februari 2011, bertepatan dengan peringatan 10 tahun piagam nasional, dan terinspirasi keberhasilan rakyat Mesir dalam menumbangkan Husni Mubarak, maka partai oposisi al-Wefaq bersuara lantang menyerukan rakyat untuk turun bersama ke jalan menuntut reformasi. Alhasil dalam waktu singkat, tujuh hari kemudian ratusan ribu rakyat Bahrain membanjiri Pearl Square yang merupakan jantung kota manama. Kehadiran ratusan ribu pengunjuk rasa menjadi bukti bahwa partai al-Wefaq berhasil menjadi motor dalam gerakan masa tersebut. Seorang koresponden al-Jazeera Bahrain mengatakan ribuan demonstran menguasai bundaran mutiara yang merupakan landmark Manama.

"Mereka terorganisasi dengan baik, mereka mengatakan akan menjadikan bundaran Mutiara di Manama layaknya Bundaran Tahrir di Kairo.” (Republika, 2011)

Gerakan massa yang terorganisir yang dipimpin oleh oposisi juga diamini oleh perwakilan Indonesia untuk Bahrain.

"Sebetulnya ada aktivis oposisi yang menggerakkan unjuk rasa. Rakyat sebenarnya menuntut apa yang dianggap sebagai diskriminasi sistemik oleh pemerintah seperti meminta perlakukan sama dan lapangan kerja serta untuk mendapatkan rumah," kata Kuasa Usaha Sementara KBRI Bahrain, Agus Salim. (BBC, 2018).

Gerakan massa menuntut reformasi dimulai pada tanggal 14 Februari 2011, dengan pusat aksi di Bundaran Mutiara, Manama. Gerakan ini juga didukung oleh anak muda Bahrain 
yang ikut menggerakkan aksi protes lewat jejaring sosial, diantaranya sebuah halaman Facebook terdapat ajakan melakukan revolusi sebagaimana yang terjadi di Mesir yang langsung direspon 14 ribu pengikut (Tempo, 2011).

Selain itu, terdapat tokoh yang cukup memiliki peran dalam gerakan massa yang terjadi adalah Hasan Mushaima, pemimpin gerakan Haq. Mushaima adalah salah satu dari 25 orang yang diasingkan oleh Pemerintah Bahrain tahun 2010 atas tuduhan kudeta (Tan Sulaiman). Pada 26 Februari 2011, Hassan Mushaima kembali dari pengasingannya di London setelah mendapatkan pengampunan dari Raja Hamad. Kedatangan Mushaima disambut luar biasa oleh pendukungnya. Mereka memeluk dan mencium pemimpin utama Syiah tersebut. Mushaima pun langsung berseru agar raja Hamad melaksanakan janji reformasinya.

"Dialog.....tidaklah cukup. Janji tidak cukup. Kita harus melihat akar masalah kata Mushaima kepada reporter setibanya di bandar udara. Penguasa Bahrain, katanya, sudah berjanji tetapi tidak melakukan apapun" (Kompas, 2011).

Berbagai kelompok dan tokoh di atas merupakan salah satu faktor yang mendorong terjadinya gerakan massa karena mereka mempunyai sumber daya dan mampu memobilisasi rakyat, dimana rakyat Bahrain sejak awal sudah kecewa terhadap rezim al-Khalifa.

\section{Gerakan Massa Di Mesir Sebagai Kondisi Khusus}

Akumulasi kekecewaan rakyat bahrain terhadap pemerintahan al-Khalifa sudah tertumpuk sejak lama. Namun rakyat Bahrain belum mendapatkan momentum tepat untuk melakukan protes besar-besaran terhadap pemerintah. Adanya momentum keberhasilan rakyat Mesir menjatuhkan rezim Husni Mubarak telah menstimulus rakyat Bahrain mempunyai keberanian untuk melakukan gerakan serupa. Hal ini terbukti dengan meletusnya gerakan massa menuntut reformasi di Bahrain pasca tiga hari lengsernya Husni Mubarak di Mesir. Berawal dari Mesir, dimana gerakan rakyat telah berhasil menggulingkan pemmpin otoriter Husni Mubarak yang telah berkuasa selama 30 tahun.

Gerakan massa memprotes Husni Mubarak dimulai pada tanggal 25 januari 2011. Dalam waktu singkat jutaan rakyat Mesir telah memenuhi bundaran Tahrir yang merupakan pusat gerakan protes. Para demonstran menuntut Husni Mubarak untuk mundur.selain itu mereka juga menuntut penghapusan UU Darurat. Setelah 18 hari berjuang, maka usaha rakyat mesir membuahkan hasil. Pada tanggal 1 Februari 2011, Presiden Husni Mubarak menyatakan mundur dan pemimpin sementara di Mesir dipegang oleh militer (Aljazeera, 2011). 
Kejatuhan mubarak pada 11 Februari 2011 nampaknya disambut sukacita bagi gerakan pro rakyat di kawasan Timur Tengah tidak terkecuali rakyat Bahrain yang selama 40 tahun telah hidup dalam ketidakadilan dan diskriminasi yang dilakukan oleh penguasa. Tepat tiga hari pasca lengsernya Mubarak, momentum tersebut telah dipergunakan dengan baik oleh rakyat Bahrain dengan turun ke jalan untuk menuntut reformasi. Mereka meminta diakhirinya kekuasaan yang terlalu luas bagi pihak kerajaan, diakhirinya diskriminasi di semua sektor yang dilakukan oleh pemerintah, menuntut dipilihnya perdana menteri, reformasi lembaga legislatif, dan peradilan yang bebas dan adil.

Rakyat Bahrain sudah lama memendam kekecewaan terhadap pemerintahan Manama. Keberhasilan rakyat Mesir yang notabene mengalami keadaan yang serupa telah menginspirasi mereka. Jika Mesir bisa, kenapa kita tidak. Begitulah kira-kira slogan perubahan yang telah menancap di hati rakyat Bahrain. Selain momentum waktu dan nasib yang sama, adanya dukungan internasional pro perubahan yang dialami rakyat Mesir juga menjadi kondisi khusus yang patut digarisbawahi. Seperti halnya yang terjadi di Mesir, dukungan internasional mendukung aksi damai yang dilakukan oleh rakyat Bahrain dalam menuntut reformasi juga telah mengalir. Seperti yang dinyatakan oleh Pemimpin tertinggi Republik Islam Iran, Ali Khamenei:

"Protes rakyat bahrain sah dan tepat, bila seseorang yang memiliki cara pandang benar mengenai kondisi rakyat Bahrain, bentuk pemerintahan dan cara para penguasa memanfaatkan kekuasaaan, pasti ia mengutuk perilaku pemerintah Bahrain menumpas rakyatnya," (Will Fulton, 2011)

Gerakan protes terhadap pemerintah di Mesir disebabkan oleh faktor yang tidak jauh berbeda dengan keadaanyang dialami oleh rakyat Bahrain, yaitu minimnya kekuasaan rakyat dalam berpolitik yang berujung pada diskriminasi di bidang sosial ekonomi, dan hukum. Oleh sebab itu rakyat Bahrain mendapatkan momentum untuk melakukan gerakan serupa. Sehingga momentum gerakan massa di Mesir merupakan kondisi khusus yang menginspirasi rakyat Bahrain untuk menuntut reformasi pada tahun 2011.

\section{KESIMPULAN}

Gerakan massa menuntut reformasi di Bahrain pada tanggal 15 Februari 2011 disebabkan oleh beberapa faktor, yaitu akumulasi kekecewaan rakyat terhadap pemerintahan al-Khalifa, adanya organisasi dan tokoh yang mampu memobilisasi massa serta kondisi khusus yang menginspirasi terjadinya gerakan massa tersebut. Rakyat Bahrain telah mengalami kesengsaraan selama empat puluh tahun masa kepemimpinan pemerintahan al- 
Khalifa. Hal tersebut menyebabkan rakyat mengalami akumulasi kekecewaan terhadap pemerintahan al-Khalifa. Kekecewaan rakyat terhada pemerintahan al-Khalifa menyebabkan rakyat berani memprotes pemerintah meskipun pemerintah menjalankan pemerintahan secara represif.

Salah satu kekecewaan rakyat Bahrain adalah kebijakan pemerintahan al-Khalifa di bidang politik. Kehidupan rakyat Bahrain di bidang politik pada saat dipimpin oleh pemerintahan al-Khalifa sangat tertekan. Hal tersebut terjadi karena rakyat Bahrain tidak mempunyai kebebasan serta dibatasi partisipasinya dibidang politik. Selain itu rakyat juga mengalami kekecewaan dalam bidang sosial ekonomi, dan hukum. Kekecewaan itu muncul akibat dari kebijakan diskriminatif pemerintahan al-Khalifa terhadap mereka.

Selain akumulasi kekecewaan rakyat, adanya organisasi dan tokoh yang mampu memobilisasi massa merupakan faktor penyebab terjadinya gerakan massa di Bahrain. Alwefaq, Hasan Mushaima, kelompok Waad merupakan organisasi dan tokoh yang mampu memobiliasasi massa yang sudah kecewa terhadap pemerintahan al-Khalifa. Rakyat yang berada dalam suatu kelompok terorganisir akan lebih mudah untuk bergabung dalam aksi seperti gerakan massa di Bahrain. Akumulasi kekecewaan dan adanya organisasi serta tokoh yang memobilisasi massa saja tidak cukup untuk mendorong terjadinya gerakan massa di Bahrain. Faktor pemicunya adalah suatu kondisi khusus. Dalam hal ini kondisi khusus tersebut adalah keberhasilan rakyat Mesir menjatuhkan rezim Husni Mubarak melalui gerakan massa. Oleh sebab itu dengan kemiripan keadaan dalam negeri, rakyat Bahrain mendapatkan momentum untuk melakukan gerakan serupa di Bahrain. 


\section{DAFTAR PUSTAKA}

Coates Ulrichsen, K. (2013). Bahrain's Uprising. In F. Gerges (Ed.), The New Middle East: Protest and Revolution in the Arab World (pp. 332-350). Cambridge: Cambridge University Press. doi:10.1017/CBO9781139236737.018.

Nuruzzaman, M. (2013). Politics, Economi cs and Saudi Military Intervention in Bahrain', Journal of Contemporary Asia [online] 43(2), pp.363-378. Dalam: https://www.tandfonline.com/doi/abs/10.1080/00472336.2012.759406 [Accessed 14 Oktober 2020].

Katzman, Kenneth. (2010). Bahrain: Reform, Security, and U.S Policy [Online], Congresional Research Service. Available at: $<$ https://www.everycrsreport.com/files/20100929 951013 e9c24e9229ea529b7df0adcce0b3c284ae976818.pdf> [ 03 March 2021].

Gamson, W. A. (1992). The social psychology of collective action. In A. D. Morris \& C. M. Mueller (Eds.), Frontiers in social movement theory (p. 53-76). Yale University Press.

Mabon, Simon. (2020). Protest, Sect, and The Potential for Power Sharing in Bahrain. Lancaster University. Studies in Ethnicity and Nationalism: Vol. 20, No. 2, 2020 pp.161-168. Dalam https://onlinelibrary.wiley.com/doi/epdf/10.1111/sena.12332 [Accessed 10 March 2021].

David Pollock (2017) Sunnis and Shia in Bahrain: New Survey Shows Both Conflict and Consensus [Online], Washington Institute. Available at:https://www.washingtoninstitute.org/policy-analysis/sunnis-and-shia-bahrain-newsurvey-shows-both-conflict-and-consensus [accessed on 03 March 2021].

HRW (1997) Bahrain: Report Charges Persistent Violations of Civil Rights Contribute to Political Crisis, Urges U.S. and U.K. to End Public [Online], 23 July. Available at:< https://www.hrw.org/news/1997/07/23/bahrain-report-charges-persistent-violationscivil-rights-contribute-political $>$ [accessed on 02 March 2021].

Human Rights Watch (2009) Bahrain in World Report. New York: Human Right Watch Press. Hal.23.

ABNA (2010) Pemerintah Bahrain Melarang Keras Penyelanggaraan Aksi Solidaritas Hari Al Quds Sedunia [Online], 5 September. Available at: $<$ https://id.abna24.com/service/middleeast/archive/2010/09/05/202566/story.html > [accessed on 28 February 2021].

Kompas(2011) Bahrain dari mutiara, minyak ke Protes[Online], 17 February. Available at: $<$ https://nasional.kompas.com/read/2011/02/17/1329443/bahrain.dari.mutiara. minyak.ke.protes?page $=$ all $>$ [accessed on 28 February 2021].

BBC (2018) Bahrain Profile-Time Line[Online], 12 November. Available at: $<$ https://www.bbc.com/news/world-middle-east-14541322 12 November 2018> \{accessed on 28 February 2021]. 
IRIB (2010) Gonjang ganjing pemilu legislative Bahrain [Online], 4 Agustus. Available at: <http://indonesian.irib.ir/ranah/sosialita/item/34112-Gonjangganjing_Hasil_Pemilu_Legislatif_Bahrain 2010 Agustus> [accessed on 02 March 2021].

HRW (2011) How Bahrain is Oppressing its Shia Majority [Online], 22 May. Available at:< https://www.hrw.org/news/2011/05/22/how-bahrain-oppressing-its-shia-majority > [accessed on 02 March 2021].

Kompas (2011) Ratusan ribu Syiah melawan Rezim Sunni [Online], 23 February. Available at: https://otomotif.kompas.com/read/2011/02/23/01263136/ Internasional News [accessed on 28 February 2021].

Kompas (2011) Rakyat Bahrain tuntut monarki konstitusional [Online], 21 February. Available at: $<$ https: $/ /$ money.kompas.com $/ \mathrm{read} / 2011 / 02 / 21 / 03330550 / \mathrm{NaN}$ ?page $=$ all rakyat Bahrain tuntut monarki konstitusional $>$ [accessed on 01 March 2021].

Ahmad Hanafi (2011) Eksistensi Gerakan Syi’ah di Bahrain [Online], Wahdah Islamiyah. Available at: < https://wahdah.or.id/eksistensi-gerakan-syiah-di-bahrain/> [accessed on 03 March 2021].

Republika (2011) Setelah Tunisia dan Mesir, Kini Bahrain Digoyang Unjuk Rasa [Online], 16 February. Available at:https://www.republika.co.id/berita/164207/setelah-tunisiadan-mesir-kini-bahrain-digoyang-unjuk-rasa [accessed on 25 February 2021].

Global Muslim (2011) Aksi Protes di Bahrain Makin Besar, Raja akan Bebaskan Tahanan Politik [Online], February. Available at: $<$ https://www.globalmuslim.web.id/2011/02/aksi-protes-di-bahrain-makin-besarraja.html? $\mathrm{m}=0>$ [accessed on 01 March 2021].

Tempo (2011) Oposisi Bahrain Serukan Dermonstran Turun ke Jalan [Online], 14 February. Available at: < https://dunia.tempo.co/read/313331/oposisi-bahrainserukan-dermonstran-turun-ke-jalan $>$ [accessed on 25 February 2021].

Kompas (2011) Pemimpin Syiah pulang Bahrain memanas[Online], 27 February. Available at: < https://properti.kompas.com/read/2011/02/27/00171686/pemimpin.syiah.pulang .bahrain.memanas $>$ [accessed on 1 March 2021].

Aljazeera (2011) Protesters torch Egypt police post [Online], 27 January. Available at $<$ https://www.aljazeera.com/news/2011/1/27/protesters-torch-egypt-police-post> [accessed on 10 March 2021].

Will Fulton (2011) Bahrain - Iran Foreign Relations [Online], Critical Threat . Available at:https://www.criticalthreats.org/analysis/bahrain-iran-foreign-relations [Accessed on 03 March 2021]. 